\title{
Clinical Trial Site Task Assignment Document
}

National Cancer Institute

\section{Source}

National Cancer Institute. Clinical Trial Site Task Assignment Document. NCI Thesaurus.

Code C115673.

Records tracking the task designations made by the principal investigator to trial personnel. 